\title{
Innovative learning model with augmented reality technology for deaf students
}

\author{
Joko LiantoBuliali, Sepuluh Nopember Institute of Technoloy, buliali@its.ac.id \\ Andriyani, Ahmad Dahlan University, andriyani@uad.ac.id \\ YudhiaktoPramudya,Ahmad Dahlan University, pramudia@uad.ac.id
}

\begin{abstract}
This study aims to produce a valid, practical, and effective geometry learning model with augmented reality for deaf students. The development of this learning model uses the Borg \& Gall procedural model which consists of research and information gathering, planning, development of initial product forms, field trials, major product revisions, main field tests, operational product revisions, posttests. The quality of the learning model with augmented reality refers to valid, practical, and effective criteria. Learning with augmented reality is implemented at SLB Negeri 2 Bantul involving 10 students and a math teacher. The instruments in this study consisted of (1) instruments for assessing the validity of the contents and constructs of the model, as well as learning support tools, (2) instruments for assessing the practicality of observers who observed the implementation of the model also student response questionnaire, and (3) the effectiveness instrument which included posttest understanding sheets, observation of learning management abilities and questionnaire of students' appreciation of learning. The results showed that the learning model with augmented reality which includes aspects of supporting theory, syntax, social systems, reaction principles, learning support systems, implementation of learning models, instructional and accompaniment impacts have met the valid, practical, and effective criteria to improve deaf student's geometry concept understanding.
\end{abstract}

Keywords: Learning model, Augmented reality, Deaf, Geometry

Received: $18.11 .2020 \quad$ Accepted: 22.12 .2020

Published: 05.01 .2021

\section{INTRODUCTION}

Special education is the education specifically provided for students with physical or mental disabilities as stipulated in the Law of the Republic of Indonesia Number 2 of 1989. This means, that deaf-mute people as physically disabled are also entitled to obtain proper education in extraordinary educational. But, it found that special education services are still segmented. Even though the inclusion system has been opened as a form of educational service for deaf people, but there are still schools that refuse to accept them due to limited human resources. This fact shows that deafness possessed by deaf people creates a negative stigma against them (Sulisworo, 2020).

Deaf children have hearing and verbal communication limitations. According Zeng \& Djalilian (2010), deafness means the inability to completely hear any type of sound. Whereas Thompson (2010) said, hearing loss experienced by children with hearing impairment causes speech delays. The implications of limited communication and knowledge make children with hearing impairment lag behind in learning mathematics compared to their normal peers (Gottardis, Nunes, \& Lunt, 2011). Even though deaf students did better on math assignments, deaf students result still had lower than hearing students who were unable to learn (Caemmerer, Cawthon, \& Bond, 2016). This in line with the results of trend analysis in mathematics achievement of American students over a period of three decades which show that the consistency of the performance of deaf-mute and impaired hearing of students lower than students who have hearing (Qi \& Mitchell, 2012). Beside that low learning achievement, deaf students also have the high mathematical anxiety (Ariapooran, 2017). This implicasted the focus of several recent studies on mathematics learning for deaf students (Pagliaro \& Kritzer, 2013;Vesel \& Robillard, 2013; Shelton \& Parlin, 2016;Ariapooran, 2017;Techaraungrong, Suksakulchai, Kaewprapan, \& Murphy, 2015).

In learning mathematics, deaf students have weaknesses in several cognitive and psychomotor aspects, namely reasoning and numerical operations (Bull et al., 2011), as well as measurement and problem solving (Pagliaro \& Kritzer, 2013). These weaknesses are related to their hearing loss which also results in major constraints such as inadequate knowledge, deficits in social skills, language delays, 
vocabulary delays, literacy delays, gaps in background and domain knowledge, dependence on technology assistance and use of strategies (Luckner, Slike, \& Johnson, 2012).

One of the math topics that deaf students feel difficult to study is geometry (Gal \& Linchevski, 2010; Adolphus, 2011). Geometry is a branch of mathematics that is better known to students than other branches because its basic concepts were first recognized by students through the playing environment or informal education at the stage of its concrete operational development (Andriyani \& Juniati, 2020). Many objects around students are models of geometry shapes that intuitively and visually have their understanding captured when students classify these objects into certain set of shapes. Even though geometry objects are familiarly known in students' daily lives, there are still many students who think that geometry is a difficult material to learn.

The important role of geometry in learning mathematics does not necessarily mean that teachers always prepare appropriate material and master geometry well because many teachers are not ready to teach geometry (Jones, Mooney, \& Harries, 2002). This teacher unpreparedness has implications for the mastery of the geometric competences of deaf students who actually tend to dislike learning with textbooks only. They prefer learning the features with a lot of visual teaching materials and direct experiences. Therefore, teachers need to choose a learning model that is tailored to the limitations of students, attracts learning interest, stimulates curiosity, is interactive when used, and does not reduce the essential materials presented. According to Adler et al (Adler, Jacob, Kurz, \& Kusha, 2014) deaf students need more attention and significant changes in improving the quality of learning. Teaching and learning material must facilitate necessaries and accommodate the unique characteristics (Hasanah, Kusumah, \& Ulya, 2017).

In learning, teachers need to pay attention to the characteristics of deaf people who depend more on sight than hearing in both communication and information processes (for example Marschark, Morrison, Lukomski, Borgna, \& Convertino, 2013; Marschark et al., 2017). Thus, the selected learning model has to emphasize the importance of visual displays to accompany verbal descriptions so that the learning material can be understood by students. As an alternative, a virtual environment is capable of loading three-dimensional visualizations generated via computer graphics. According to Kesim \& Ozarslan (2012), the opportunity for a virtual environment that is presented in cyberspace has a great opportunity to be used in the teaching and learning process although it is still difficult to provide an adequate level of realism. Both students and teachers who use this media are completely separate from the real environment.

In a different way, augmented reality technology actually allows users to see the real world while virtual elements are superimposed or combined with the real world (Sutherland, 1968). By this way, augmented reality enriches users' perceptions of reality, not replacing it completely as in a virtual environment so that students can visualize objects they previously had difficulty imagining. Not only that, augmented reality also reveals object entities through the recognition of physical objects so that users can understand and exploit the properties of these physical objects (Ariso, 2017).

Real-time augmented reality technology combines real and virtual objects in real 3D space (Azuma, 1997). Woods et al. (2004) stated that augmented reality can be used to present and explore 2D spatial problems that are difficult for students to understand in 3D. With augmented reality technology, students 'spatial abilities can be developed (Seichter, 2007). According to Pemberton \& Winter (2009), the use of a collaborative augmented reality environment can support students' conceptual understanding and knowledge acquisition through group work and reflection on their experiences. Augmented reality is a new opportunity to support the mathematics learning process (Schallert \& Lavicza, 2020).

Based on the preliminary research at SLB Negeri 2 Bantul, it was found that the conceptual understanding of circles in deaf students was low because mentally they could not represent some of the circular elements contained in the circle contextual problem. In view of the limitations of the deaf and their interest in visual learning and direct experience, a mathematical learning model based on visualization and exploration with direct experience is needed. Therefore, in this study, a learning model based on an augmented reality framework was developed with the aim of producing a mathematical learning model based on visualization and object manipulation which includes aspects of syntax, social systems, reaction principles, support systems, instructional impact and companion. The model is expected to meet the criteria of validity, practicality and effectiveness so that it can be applied in learning geometry for deaf students.

\section{METHODS}

This study was conducted by using Research and Development (R\&D) method to produce a product in the form of a learning model and test the effectiveness of the product (Sugiyono, 2011). The development 
model used was a procedural model by Borg \& Gall which is descriptive and shows the systematic step to produce (Puslitjaknov, 2008) and (Borg \& Gall, 2003). The development steps taken include: research and information collecting, planning, developing preliminary form of product, preliminary field testing, main product revision, main field testing and operational product revision. The steps are illustrated as in Figure 1 below.

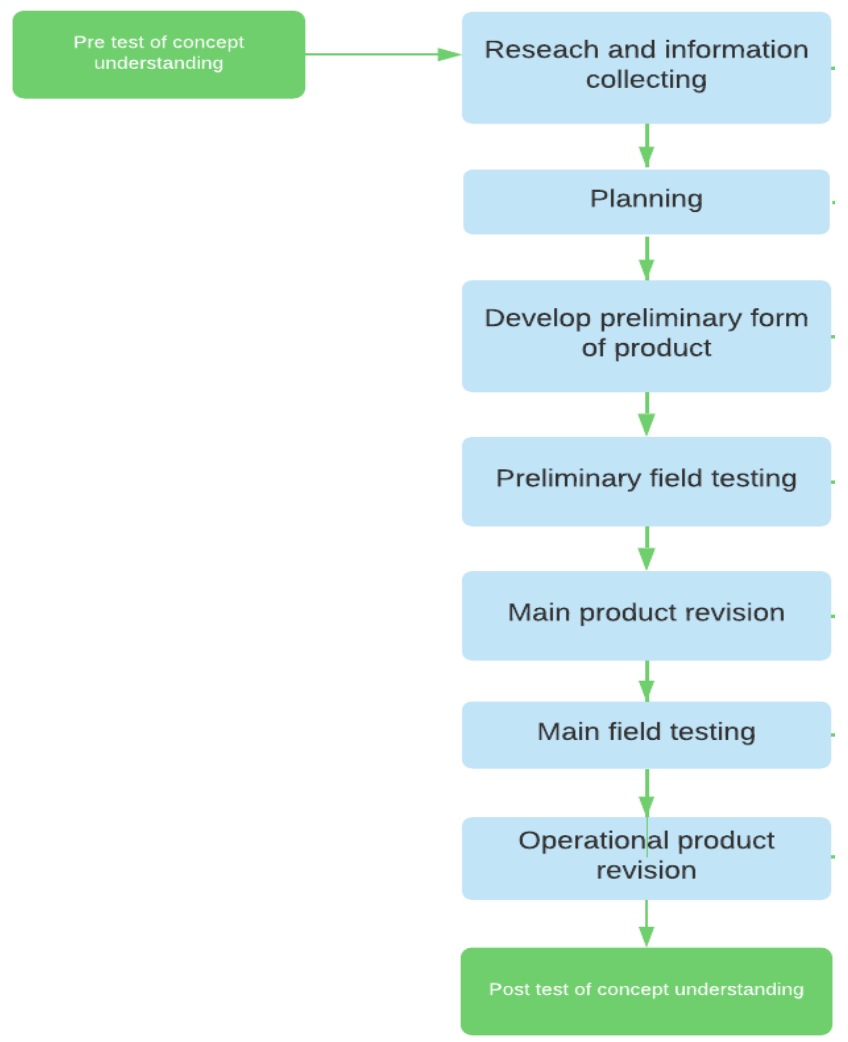

Figure 1. Research flow diagram

The subjects in this study were 10 deaf students at SLB Negeri 2 Bantul who had studied geometry, especially circles. The instrument used to collect the data was an understanding test instrument containing seven indicators of understanding according to Anderson \& Krathwohl (2001); learning style test instruments; interview guide instruments; questionnaire of content validation, construct validation, observation instruments for the implementation of learning models, observation instruments for teachers' abilities in managing teaching and learning activities and questionnaire for student responses. The seven indicators of the understanding test are interpreting, exemplifying, classifying, comparing, explaining, summarizing and inferring. The data collection technique was through giving understanding test before and after the model implemented by using learning style tests, interviews, validation questionnaires by three practitioners and one expert and student response questionnaires.

Data analysis was carried out by analyzing the feasibility of the model in terms of the validity, practicality and effectiveness of the learning model. The validity of the learning model is determined by the judgment of practitioners and experts. The scores obtained from the assessment sheet for the validity, practicality and effectiveness of the learning model are then converted into qualitative categorization by referring to the qualitative categorization according to Azwar (2010)) which consists of five criteria as in table 1 below.

Table 1. Criteria for converting quantitative data to qualitative data

\begin{tabular}{|c|c|c|}
\hline No & Score & Criteria \\
\hline 1 & $M_{i}+1,5 s b_{i}<X \leq M_{i}+3 s b_{i}$ & Very good \\
\hline 2 & $M_{i}+0,5 s b_{i}<X \leq M_{i}+1,5 s b_{i}$ & Good \\
\hline 3 & $M_{i}-0,5 s b_{i}<X \leq M_{i}+0,5 s b_{i}$ & Enough \\
\hline 4 & $M_{i}-1,5 s b_{i}<X \leq M_{i}-0,5 s b_{i}$ & Less \\
\hline 5 & $M_{i}-3 s b_{i}<X \leq M_{i}-1,5 s b_{i}$ & Not good \\
\hline
\end{tabular}


The learning model is said to be valid if the expert's assessment of the minimum component of the learning model and learning support devices reaches the good criteria. More than that good criteria, the model included very valid. Furthermore, the learning model is said to be practical if the results of the observation of the assessment of the implementation of the learning model and the minimum results of the student response questionnaires reach good criteria. More than that good criteria, the model included very practical.The effectiveness of learning is determined by the results of the teacher's ability to apply the learning model and the posttest results of students are higher than the results of the pretest understanding.

\section{RESULTS}

The result of the development in this study is a learning model based on an augmented reality framework. The following are the results obtained from development research in accordance with the development steps illustrated in Figure 1 above.

\section{Research and information collecting}

In this case the researcher has conducted a literature study related to the characteristics and learning styles of the deaf, Android-based augmented reality, the concept of geometry and its transformation, and the rotation of celestial bodies in the solar system. Researchers have also carried out observations, interviews and pretest of students' understanding with mathematics and science teachers at SLB Negeri 2 Bantul. Based on the results of observations and interviews, it is known that:

a. From a teacher perspective

1. The teacher finds it difficult to teach abstract geometric concepts to deaf students who have limited verbal communication, vocabulary and knowledge also in rotation of celestial bodies in the solar system. The teacher never teaches the physics material because of the teacher's limited competence to teach the material.

2. The teacher really needs a model and innovative learning media that is in accordance with the deafness barrier, especially those related to the physiological structural abnormalities of the sense of hearing and pronunciation.

b. From a student perspective

1. Students' interest in learning is low because the learning carried out by the teacher is expositorier, while students experience obstacles in verbal communication. This makes students often feel bored with the monotonous and one-way learning model.

2. The instructional media used by the teacher is in the form of textbooks containing text descriptions of concepts and a collection of formal geometric formulas, so that students tend to memorize concepts and not interpret them.

3. Students have difficulty in understanding the concept; this is indicated by the low comprehension test results. According to students, the absence of learning media that can represent concepts clearly and interactively is the reason for their lack of understanding of the material.

Based on the results of the deaf students' understanding test at SLB Negeri 2 Bantul, it is known that the understanding of the ten students varies. The maximum value achieved by students in understanding the concept was 39 while the minimum score for understanding the concept was 18. Meanwhile, the overall average understanding of the concept was 29.33, which means that the student's understanding is lower than the minimum completeness criteria set by the school, which are 60 . This shows that the understanding of deaf students is very low. The mean distance of the deviation from the score of each student's comprehension test to the mean score was 7.38 as indicated by the standard deviation value. The description of the test results for the understanding of the geometry concepts of the deaf students is presented in table 2 below.

Table 2. Average value, standard deviation, highest value, lowest value of 9 students at SLB Negeri 2 Bantul

\begin{tabular}{|l|l|l|}
\hline No. & Statistics & Score \\
\hline 1 & Respondent (N) & 10 \\
\hline 2 & Test Ideal Value & 100 \\
\hline 3 & Maximum Test Value & 39 \\
\hline 4 & Minimum Test Score & 18 \\
\hline 5 & Average & 29,33 \\
\hline
\end{tabular}




\begin{tabular}{|l|l|l|}
\hline 6 & Standard Deviation & 7,38 \\
\hline
\end{tabular}

Besides carrying out observations, interviews, and pretest on concept understanding, researchers also examined the learning styles of deaf students at SLB Negeri 2 Bantul using learning style tests. Based on the results of the learning style test, it was found that the percentage of students who had a visual learning style was 50\% (5 students), 40\% (4 students) had a kinesthetic learning style and $10 \%$ ( 1 student) had a combination of both visual and kinesthetic learning styles. The description of the learning style of deaf students at SLB Negeri 2 Bantul is presented in Figure 2 below.

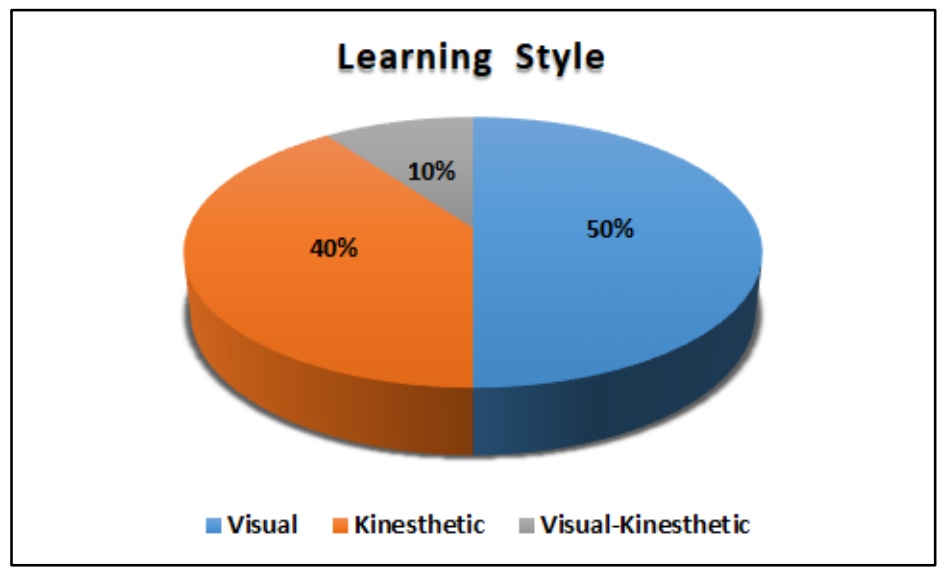

Figure 2. Deafstudent learning styles at SLB Negeri 2 Bantul

The results of the needs analysis above serve as the basis for researchers to develop learning models that accommodate obstacles, student characteristics, and their needs in learning geometry.

\section{Planning and developing a preliminary form of product}

At this stage the researchers developed instruments to validate the learning model which included content validation instruments, construct validation instruments, model implementation observation instruments, teachers' ability to manage learning instruments, student response instruments, learning style instruments, and comprehension instruments for posttests. After developing the instrument, the researcher developed a learning model based on an augmented reality framework. In an augmented reality framework, physical objects are used to intuitively manipulate virtual information, then it is combined with virtual elements (Andriyani \& Juniati, 2020). Disclosure of object entities through the recognition of physical objects is carried out to understand and exploit the properties of these physical objects (Ariso, 2017). This framework is applied to a learning model related to students' cognitive understanding of concepts. In understanding mental activities, students assimilate external stimuli into a mental structure or a collection of concepts that are interrelated in a particular relationship.

The learning model developed is in the form of learning which contains five learning steps, namely orienting students to the introduction of concrete objects, organizing students to abstract concrete objects, guiding students in expanding the results of recognizing concrete objects, analyzing and evaluating, and generalizing the development of object recognition results. In developing this model, the researcher also considers aspects of the social system. The results of expert assessments of the validity of the contents and constructs of the learning model can be seen in table 3 and table 4 below.

Table 3. Scores and criteria for assessing the content validity of the learning model with augmented reality

\begin{tabular}{|l|l|c|c|}
\hline No. & \multicolumn{1}{|c|}{ Content Validity Aspects } & Score & Criteria \\
\hline 1 & Supporting theory & 4,58 & Very Valid \\
\hline 2 & Syntax & 4,57 & Very Valid \\
\hline 3 & Social system & 4,57 & Very Valid \\
\hline 4 & Reaction principle & 4,67 & Very Valid \\
\hline 5 & Supporting system & 4,56 & Very Valid \\
\hline 6 & Instructional and accompaniment impact & 4,38 & Very Valid \\
\hline
\end{tabular}




\begin{tabular}{|l|l|l|l|}
\hline 7 & Learning model implementation & 4,67 & Very Valid \\
\hline
\end{tabular}

Table 4. Scores and criteria for assessing the construct validity of learning model with augmented reality

\begin{tabular}{|l|l|c|c|}
\hline No. & \multicolumn{1}{|c|}{ Content Validity Aspects } & Score & Criteria \\
\hline 1 & Supporting theory & 4,53 & Very Valid \\
\hline 2 & Syntax & 5,00 & Very Valid \\
\hline 3 & Social system & 4,76 & Very Valid \\
\hline 4 & Reaction principle & 4,33 & Very Valid \\
\hline 5 & Supporting system & 4,67 & Very Valid \\
\hline 6 & Instructional and accompaniment impact & 4,67 & Very Valid \\
\hline 7 & Learning model implementation & 4,21 & Valid \\
\hline 8 & Supporting theory & 4,57 & Very Valid \\
\hline
\end{tabular}

Furthermore, the results of a brief assessment of the validity of learning support devices can be seen in table 5 below.

Table 5. Score and criteria for assessment results

\begin{tabular}{|l|l|c|c|}
\hline No. & \multicolumn{1}{|c|}{ Product } & Score & Criteria \\
\hline 1 & Lesson plan & 4,45 & Very Valid \\
\hline 2 & Students' worksheet & 4,50 & Very Valid \\
\hline
\end{tabular}

Based on the results of expert judgment to the validity of the content of the learning model with augmented reality in table 3 , it is known that the learning aspects reach very valid criteria. Also to the construct validity of the learning model that reaches very valid criteria as in table 4 . The validity of the model is also supported by the very validity of learning support tools which include the Learning Implementation Plan and Student Worksheets such as the results of the assessment presented in table 5. Thus, the learning model with augmented reality has met the validity criteria of a learning model.

The learning model with augmented reality has met valid criteria by paying attention to aspects of supporting theory, syntax, social system, reaction principle, support system, learning model implementation, instructional and accompaniment impact. Supporting theories are related to theories that support the development of learning models with augmented reality, the meaning of principles, goals and the relationship between theory and the characteristics of mathematics in learning. The learning syntax with augmented reality begins with the stage of orienting students to the introduction of concrete objects, the stage of organizing students to abstract concrete objects, the stage of guiding students in expanding the results of recognizing concrete objects, the stage of analyzing and evaluating, then ends with the stage of generalizing the development of object recognition results. This social system in learning with augmented reality includes the roles and relationships of students and teachers in detail at each stage of their learning. The principle of reaction is related to the role of the teacher in learning. The support system needed to be able to implement the augmented reality learning model is the students' worksheet to support geometry learning and augmented reality technology to visualize geometric abstract objects that students are learning and they find difficult to imagine. The implementation of the model is related to the suitability of the details of planning tasks during learning and assessment with supporting theories. Furthermore, the final component in the problem-based mathematics learning model is the instructional impact and the accompanying impact. Instructional impacts include: the process of understanding concepts, mastery of basic competencies and the ability to construct knowledge. The achievement of basic competencies can be shown from student learning outcomes, while the process of understanding concepts has also been carried out in most of the implementation of learning based on observations of learning implementation. Accompanying impacts include: cooperative skills, self-control, self-confidence, self-esteem, cooperation and students' motivation.

\section{Preliminary field testing and main product revision}

At this stage the researcher collected and analyzed the test results of the learning model through interviews, observations, and questionnaires for 2 students as a qualitative evaluation of the product content and obtained valid results without revision. 


\section{Main field testing, operational product revision and posttest}

At this stage the researchers applied a learning model on a larger scale, involving all students with hearing impairment at SLB Negeri 2 Bantul. Based on the results of trials of learning models in schools, it can be seen that the practicality of learning models with augmented reality is assessed from observations of the implementation of the learning model and the results of student response questionnaires.

Table 6. Scores and criteria for learning model implementation assessment results

\begin{tabular}{|l|l|l|l|}
\hline No. & Content Validity Aspects & Score & Criteria \\
\hline 1 & Syntax & 4.63 & Very practical \\
\hline 2 & Social System & 4.54 & Very practical \\
\hline 3 & Principle of Reflection & 4.75 & Very practical \\
\hline
\end{tabular}

Based on Table 6 above, it is known that all aspects of learning, namely syntax, social systems and the principle of reflection can be implemented very well, meaning that during learning the implementation of the learning model reaches very practical criteria. The results of the student response questionnaire also showed that the learning model with augmented reality met the very practical criteria as presented in table 7 below.

Table 7. Scores and criteria for student response questionnaire results

\begin{tabular}{|l|c|}
\hline \multicolumn{2}{|c|}{ Total } \\
\hline Actual score & 8,14 \\
\hline Criteria & Very practical \\
\hline Percentage of answers 'Yes' & 90,26 \\
\hline
\end{tabular}

From the results of the observer's assessment of the implementation of the learning model and the results of the student's response questionnaire above, it can be said that the learning model developed has fulfilled the practicality of a learning model. Furthermore, to see the effectiveness of the learning model, an analysis of the test scores was carried out on the assessment of the teacher's ability to manage learning and test scores for understanding geometry. After implementing the learning model in schools, observations of the teacher's ability to manage learning using this model were obtained as presented in table 8 below.

Table 8. Scores and Criteria Results of the assessment of the teacher's ability to manage learning

\begin{tabular}{|l|l|l|l|}
\hline No. & \multicolumn{1}{|c|}{ Scored aspects } & Score & \multicolumn{1}{|c|}{ Criteria } \\
\hline 1 & Oriented students on the introduction of concrete objects & 4.83 & Very high \\
\hline 2 & Organizes to abstract concrete objects & 4.75 & Very high \\
\hline 3 & Guide students to expand the results of concrete object recognition & 4.83 & Very high \\
\hline 4 & Analyze and evaluate student understanding & 4.55 & Very high \\
\hline 5 & Generalizing the development of object recognition results & 4.78 & Very high \\
\hline
\end{tabular}

From table 8 it can be seen that the teacher's ability to manage learning using an augmented reality learning model is very high. This shows that the learning steps contained in the model help teachers manage geometry learning very well. The implementation of the learning model for deaf students at SLB Negeri 2 Bantul also has implications for understanding the concept of geometry of deaf students there. This is supported by the increase in students' post test scores from their pretest scores as illustrated in Figure 3 below. 


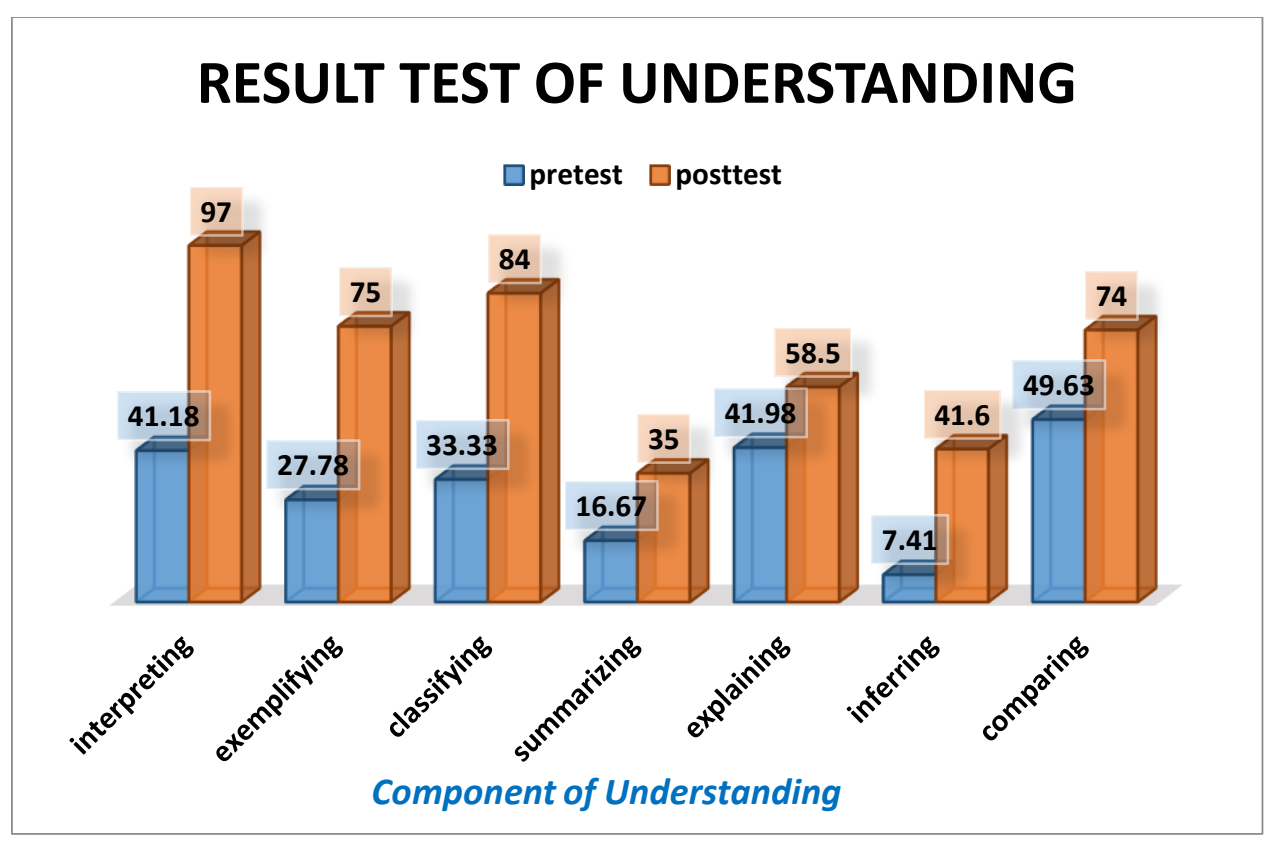

Figure 1. Result Test of Understanding Based on Seventh Components of Understanding

From the seven components of understanding, it can be seen that there are four components of understanding that have satisfy the minimum completeness criteria, that is 60 . It components are interpreting, exemplifying, classifying and comparing components. Even though before being given a learning model with augmented reality, none of the seven components of understanding satisfy the minimum completeness criteria in learning geometry. Results of the analysis teacher's ability to manage learning and increment of understanding score test (from pretest to posttest) showed that the learning model had satisfy the criteria for the effectiveness of a learning model.

Furthermore, to see students' appreciation of learning with augmented reality, the researcher gave a student response questionnaire. Based on the results of the student response questionnaire, it is known that students' appreciation of learning is very high. To see the relationship between student appreciation and the results of understanding the concept, the researcher conducted a correlation analysis. Based on the results of the correlation analysis between students' appreciation of learning and the results of the comprehension test, the correlation coefficient was $r=0.713$. Based on the results of the significance test of the correlation coefficient, it can be concluded that there is a positive correlation between students 'appreciation of learning and students' understanding of concepts.

Based on all the studies above, it can be stated that the development of a learning model with augmented reality is a learning model that has been tested for its validity, practicality and effectiveness, so that it can be considered to be used in learning geometry. Student appreciation is very high for this learning model because the model contains visualization of concepts and meaningful direct experiences. This is in line with the results of research by Bujak et al. (2013) which produced experiences through augmented reality that can help students better understand abstract concepts and facilitate meaningful experiences for students.

The success of teachers to improve the student' understanding, class management and learning models that are suitable for students, shows the quality and effectiveness of teachers in teachinglearning(Andriyani, Karim, \& Fahmi, 2020). Therefore, mastery of the material is not sufficient for a teacher. The teacher must also have the ability to plan and implement learning well, activate students, encourage problem-solving, discovery, and collaborationamong students so that learning mathematic not monotonous and boring. All these abilities can be packaged by the teacher in a learning model with augmented reality that optimizes the interaction between elements contained in the teaching-learning process and involvement of all students' senses during the learning process.By optimizing sense involvement, students can better use their reasoning and intuition so as to minimize misconceptions when interpreting a concept. This in line with (Andriyani \& Juniati, 2019), that to understand something usually a person's conception constructed on common sense or intuitively. Furthermore, conception is also influenced by one's cognition in interpreting a concept (Andriyani, Budayasa, \& Juniati, 2018). 


\section{CONCLUSIONS}

Based on the development stages carried out, an augmented reality learning model has been generated. Learning models with augmented reality that meet valid, practical, and effective criteria contain aspects (1) supporting theory; (2) learning syntax which consists of learning steps: a) orienting students towards the introduction of concrete objects, b) organizing students to abstract concrete objects, c) guiding students in expanding the results of recognizing concrete objects, d) analyzing and evaluating, e) generalize the development of object recognition results; (3) social system; (4) reaction principle; (5) learning support system; (6) implementation of the learning model; (7) instructional and accompaniment impact.

The validity of the learning model is based on the assessment of practitioners and experts in terms of content validity, construct validity and learning support devices that reach the very valid criteria. The practicality of the learning model that based on an assessment of the implementation of the learning model and the results of the student response questionnaire has reached the very practical criteria. The effectiveness of the learning model based on the assessment of the teacher's ability to manage learning is very high, improving the understanding concept that satisfy the minimum completeness criteria of learning, and the students' appreciation of learning is very high. In addition, there is a positive correlation between students' appreciation of learning and the results of understanding the concept with a correlation coefficient of $r=0.713$. The implementation of the learning model developed in this study has implications for increasing the understanding of deaf students' abstract concepts of geometry material that was previously difficult to understand. This augmented reality learning model creates collaborative learning around virtual content and the environment that facilitates meaningful experiences for students. So that this model can be used as a guide for future augmented reality-based learning experiences, especially for visualizing abstract mathematical concepts so that students can imagine them through direct experience.

\section{ACKNOWLEDGEMENTS}

The research team thank you very much to the Indonesian Ministry of Research, Technology and Higher Education who have been provided grant funds to this research. Furthermore, all members of the community academics at Ahmad Dahlan University and Sepuluh Nopember Institute of Technology who have been part of this research, both as research observers, interviewer and granting permission to conduct research.

\section{REFERENCES}

Adler, H., Jacob, B., Kurz, K., \& Kusha, R. (2014). Undergraduate research in mathematics with deaf and hard-of-hearing students: Four perspectives. A Journal of Mathematics, 3(7), 247-264.

Adolphus, T. (2011). Problems of Teaching and Learning of Geometry in Secondary Schools in Rivers State , Nigeria. International Journal of Emerging Sciences, 1(2), 143-152.

Anderson, L. W., \& Krathwohl. (2001). A Taxonomi for Learning, Teaching, and Assessing: A Revision of Bloom's Taxonomy of Educational Objectives. New York: Addison Wesley Longman Inc.

Andriyani, Budayasa, I. K., \& Juniati, D. (2018). The blind student' $s$ interpretation of two -dimensional shapes in geometry. Journal of Physics: Conference Series. https://doi.org/10.1088/1742$6596 / 947 / 1 / 012055$

Andriyani, \& Juniati, D. (2019). The Investigation of Blind Students' Misconception in Constructing Quadrilateral Analytic Definition Using Geometry's Puzzle. Journal of Physics: Conference Series, 1417(1). https://doi.org/10.1088/1742-6596/1417/1/012059

Andriyani, \& Juniati, D. (2020). Learning the relation between quadrilateral using geometry's puzzle for blind students. Journal of Physics: Conference Series, 1470(1). https://doi.org/10.1088/1742$6596 / 1470 / 1 / 012029$

Andriyani, Karim, \& Fahmi, S. (2020). The development of a Braille geometry module based on visual impairment students synthetic touch ability with RMT approach. AIP Conference Proceedings, 2215(April). https://doi.org/10.1063/5.0000577

Ariapooran, S. (2017). Mathematics Motivation, Anxiety, and Performance in Female Deaf/Hard-ofHearing and Hearing Students. Communication Disorders Quarterly, 38(3), 172-178. https://doi.org/10.1177/1525740116681271

Ariso, J. M. (2017). Augmented Reality: Reflections on Its Contribution to Knowledge Formation. Berlin: Walter de Gruyter GmbH. 
Azuma, R. T. (1997). A Survey of Augmented Reality. Teleoperators and Virtual Environments, 4(6), 355385.

Azwar, S. (2010). Tes Prestasi. Yogyakarta: Pustaka Pelajar.

Borg, W. R., \& Gall, M. (2003). Educational Research 4th Edition. Newyork: Longman Inc.

Bujak, K. R., Radu, I., Catrambone, R., MacIntyre, B., Zheng, R., \& Golubski, G. (2013). A psychological perspective on augmented reality in the mathematics classroom. Computers and Education, 68, 536544. https://doi.org/10.1016/j.compedu.2013.02.017

Bull, R., Marschark, M., Sapere, P., Davidson, W. A., Murphy, D., \& Nordman, E. (2011). Numerical Estimation in Deaf and Hearing Adults. Learning and Individual Differences, 4(21), 453-457.

Caemmerer, J. M., Cawthon, S. W., \& Bond, M. (2016). Comparison of students' achievement: Deaf, learning disabled, and deaf with a learning disability. School Psychology Review, 45(3), 362-371. https://doi.org/10.17105/SPR45-3.362-371

Gal, H., \& Linchevski, L. (2010). To see or not to see: analyzing difficulties in geometry from theperspective of visual perception. Educational Studies in Mathematics, 2(74), 163-183.

Gottardis, L., Nunes, T., \& Lunt, I. (2011). A synthesis of research on deaf and hearing children's mathematical achievement. Deafness and Education International, 13(3), 131-150. https://doi.org/10.1179/1557069X11Y.0000000006

Hasanah, A., Kusumah, Y. S., \& Ulya, Z. (2017). the Development of Mathematics Learning Media for Deaf Students: Preliminary Implementation Results. 22(2), 1-4. https://doi.org/10.18269/jpmipa.v22i2.8622

Jones, K., Mooney, C., \& Harries, T. (2002). Trainee primary teachers' knowledge of geometry for teaching. Proceedings of the British Society for Research into Learning Mathematics, 22(2), 95-100.

Kesim, M., \& Ozarslan, Y. (2012). Augmented Reality in Education: Current Technologies and the Potential for Education. Procedia - Social and Behavioral Sciences, 47(222), 297-302. https://doi.org/10.1016/j.sbspro.2012.06.654

Luckner, J. L., Slike, S. B., \& Johnson, H. (2012). Helping Students Who are Deaf or Hard of Hearing $\begin{array}{llll}\text { Succeed. TEACHING Exceptional } & \text { Children, }\end{array}$ https://doi.org/10.1177/004005991204400406

Marschark, M., Morrison, C., Lukomski, J., Borgna, G., \& Convertino, C. (2013). Are Deaf Students Visual Learners? Learning and Individual Differences, (25), 156-162.

Marschark, M., Paivio, A., Spencer, L. J., Durkin, A., Borgna, G., Convertino, C., \& Machmer, E. (2017). Don't Assume Deaf Students Are Visual Learners. Journal of Developmental and Physical Disabilities, 1(29), 153-171.

Pagliaro, C. M., \& Kritzer, K. L. (2013). The math gap: A description of the mathematics performance of preschool-aged deaf/hard-of-hearing children. Journal of Deaf Studies and Deaf Education, 18(2), 139-160. https://doi.org/10.1093/deafed/ens070

Pemberton, L., \& Winter, M. (2009). Collaborative augmented reality in schools. Proceedings of the 9th International Conference on Computer Supported Collaborative Learning - CSCL'09, 109-111. Rhodes, Greece: Association for Computational Linguistics.

Puslitjaknov, T. (2008). Metode Penelitian Pengembangan. Jakarta: Pusat Penelitian Kebijakan dan Inovasi Pendidikan Badan Penelitian dan Pengembangan Departemen Pendidikan Nasional.

Qi, S., \& Mitchell, R. E. (2012). Large-scale academic achievement testing of deaf and hard-of-hearing students: Past, present, and future. Journal of Deaf Studies and Deaf Education, 17(1), 1-18. https://doi.org/10.1093/deafed/enr028

Schallert, S., \& Lavicza, Z. (2020). Implementing Augmented Reality In Flipped Mathematic Classrooms To Enable Inquiry-Based Learning. Proceedings of 14 Th International Conference on Technology in Mathematics Teaching, 1-8. Essen: Duisburg-Essen Publication online.

Seichter, H. (2007). Augmented Reality and Tangible Interfaces in Collaborative Urban Design. In A. Dong, A. V. Moere, \& J. S. Gero (Eds.), Computer-Aided Architectural Design Futures (CAADFutures). Dordrecht: Springer Netherlands.

Shelton, B. E., \& Parlin, M. A. (2016). Teaching Math to Deaf/Hard-of-Hearing (DHH) Children Using Mobile Games: Outcomes with Student and Teacher Perspectives. International Journal of Mobile and Blended Learning, 8(1), 1-17. https://doi.org/10.4018/IJMBL.2016010101

Sugiyono. (2011). Metode Penelitian Pendidikan Pendekatan Kuantitatif, Kualitatif, dan R\&D. Bandung: Alfabeta.

Sulisworo, D. (2020). Praktik Pembelajaran Online Era Covid-19. Yogyakarta: CV Mangkubumi.

Sutherland, I. (1968). A Head-Mounted Three-Dimensional Display. Proceedings of Fall Joint Computer Conference, 757-764.

Techaraungrong, P., Suksakulchai, S., Kaewprapan, W., \& Murphy, E. (2015). The design and testing of 
multimedia for teaching arithmetic to deaf learners. Education and Information Technologies, 1(22), 215-237.

Thompson, J. (2010). The Essential Guide to Understanding Special Educational Needs. Harlow: Pearson Education Limited.

Vesel, J., \& Robillard, T. (2013). Teaching mathematics vocabulary with an interactive signing math dictionary. Journal of Research on Technology in Education, 45(4), 361-389. https://doi.org/10.1080/15391523.2013.10782610

Woods, E., Billinghurst, M., Looser, J., Aldridge, G., Brown, D., Game, B., \& Nelles, C. (2004). Augmenting the science centre and museum experience. Proceedings GRAPHITE 2004 - 2nd International Conference on Computer Graphics and Interactive Techniques in Australasia and Southeast Asia , (Figure 3), 230236. https://doi.org/10.1145/988834.988873

Zeng, F. G., \& Djalilian, H. (2010). Hearing impairment. In Book Oxford Handbook of Auditory Science: Hearing. Oxford: Oxford University Press. 